Acta Horticulturae et Regiotecturae 1

Nitra, Slovaca Universitas Agriculturae Nitriae, 2020, pp. 21-24

\title{
ISOLATION AND IDENTIFICATION OF LACTIC ACID BACTERIA IN WINE PRODUCTION BY MALDI-TOF MS BIOTYPER
}

\author{
Miroslava KAČÁNIOVÁ ${ }^{1,2 *}$, Simona KUNOVÁ ${ }^{1}$, Jozef SABO ${ }^{1}$, Eva IVANIŠOVÁ 1 , Jana ŽlAROVSKÁ1, \\ Soňa FELŠÖCIOVÁ', Katarína FATRCOVÁ-ŠRAMKOVÁ', Margarita TERENTJEVA ${ }^{3}$ \\ ${ }^{1}$ Slovak University of Agriculture, Nitra, Slovak Republic \\ ${ }^{2}$ University of Rzeszow, Rzeszow, Poland \\ ${ }^{3}$ Latvia University of Life Sciences and Technologies, Jelgava, Latvia
}

\begin{abstract}
The aim of this study was to identify lactic acid bacteria (LAB) in grapes, must and wines. A total amount of 90 samples including grape $(n=30)$, must $(n o=30)$ and wine $(n o=30)$ were collected from vineyards in Slovakia. LAB were used cultured on MRS agar with subsequent confirmation with MALDI-TOF mass spectrometry (Bruker Daltonics). Altogether, 904 isolates were identified. Members of the family Lactobacillaeceae were the most abundant in grape (60\%), must (46\%) and wine (51\%). Lactobacillus, Lactococcus, Leuconostoc, Pediococcus and Weissella genera and 27 species of LAB were isolated from the examined samples. Leuconostoc mesenteroides spp. mesenteroides was the most abundant species in grape, must and wine.
\end{abstract}

Keywords: grape, must, wine, lactic acid bacteria, MALDI-TOF MS Biotyper

The wine production is a complex process in which the microorganisms, including lactic acid bacteria (LAB), contribute to the unique sensory characteristics of wine. In general, wine is expected to be an unavailable environment for microbiological growth due to the intrinsic and extrinsic factors of the products: low $\mathrm{pH}$, high concentrations of ethanol and presence of sulfur dioxide $\left(\mathrm{SO}_{2}\right)$ (Spano and Massa, 2006). The LAB associated with wine are represented by the phylum Firmicutes, class Bacilli, order Lactobacillales, families Lactobacillaceae and Leuconostocaceae (Garrity, Bell and Lilburn, 2004). The LAB of Oenococcus, Lactobacillus, Pediococcus and Leuconostoc genera may establish bacterial growth in wine (Miranda-Castilleja et al., 2016). The recognition of the groups of wine associated microbiota was established by a combination of methods for phylogenetic analysis and allowing defining the particular groups (Makarova et al., 2006). Oenococcus oeni is considered to be adapted for growth in the wine environment, hence, it is widely applied for use in commercial MLF starter cultures. Other Lactobacillus species have exhibited a capacity to survive in wine as well (Pozo-Bayon et al., 2005). Lactobacillus plantarum is another suitable candidate for application in starter cultures. The produced enzymatic complex of L. plantarum is specifically attributed to production of $\beta$-glucosidase, which could significantly influence the sensory characteristics of wine; thus, it is important in wine production (Mtshali et al., 2009). Description of protein profile with MALDI-TOF (Matrix-assisted laser desorption/ ionization time-of-flight) mass spectrometry is a prospective method for identification of $L A B$. The results are compatible with those made by molecular methods. Therefore, MALDITOF can be considered a fast, accurate and low-cost method for identification of Gram-positive bacteria such as LAB (Rodríguez-Sánchez et al., 2016).

The aim of this study was to identify LAB collected from grape, must and wine with MALDI-TOF MS Biotyper during the technological process.

\section{Material and method}

\section{Materials}

Samples of grapes $(n=30)$ were taken gradually during the period of partial ripening of the fruit directly from the vineyards. Samples were put aseptically into polyethylene bags in August 2018 and stored at $8-10^{\circ} \mathrm{C}$ for shipping to the laboratory. Grapes from vineyards of Central Slovakia and the Nitra wine region, and private vineyards were used. Rheinriesling $(n=3)$, Welschriesling $(n=3)$, Palava $(n=3)$, Pinot Blanc $(n=3)$, and Grüner Veltliner $(n=3)$ of white varieties and Cabernet Sauvignon $(n=3)$, Blaufränkisch $(n=3)$, Blue Portugal $(n=3)$, Merlot $(n=3)$ and Pinot Noir $(n=3)$ of red varieties were sampled. Samples of new wine "must" $(n=30)$ were collected at the end of August 2018 and in the middle of September 2018 from the same winery as the grapes. Samples (apx. $100 \mathrm{~mL}$ ) were collected into $200 \mathrm{~mL}$ sterile plastic bottles with screw caps and stored

Contact address: Miroslava Kačániová, Slovak University of Agriculture, Faculty of Horticulture and Landscape Engineering, Department of Fruit Sciences, Viticulture and Enology, Trieda Andreja Hlinku 2, 94976 Nitra, Slovak Republic, Tel.: +421-905 499 166, e-mail: miroslava.kacaniova@gmail.com 
at $8-10{ }^{\circ} \mathrm{C}$. An amount of $200 \mathrm{~mL}$ of each unfiltered wine ( $n=30$ from same winery as grape and must) were collected before microfiltration) and stored at $4{ }^{\circ} \mathrm{C}$ in the refrigerator.

\section{Microbiological investigations}

For microbiological analysis, the grape samples in physiological saline were processed in $24 \mathrm{~h}$ after collection. The Man Rogosa Sharpe agar (MRS, Conda, Spain) agar medium for $L A B$ was applied for microbiological testing. The samples were diluted with sterile physiological saline $(0.85 \%)$ and decimal dilutions were plated out onto MRS agar for incubation at $30^{\circ} \mathrm{C}$ for $72 \mathrm{~h}$ microaerophilically. After incubation, the isolates were subcultured on Tryptone soya agar $90 \%$ (TSA, Basingstoke, UK) with MRS 10\% at 30 ${ }^{\circ} \mathrm{C}$ for $24 \mathrm{~h}$. Typical LAB colonies were identified with MALDITOF MS Biotyper (Bruker Daltonics, Germany) (Doan et al., 2012).

\section{Mass spectrometry identification of isolates}

Qualitative analysis of $L A B$ isolates was performed with MALDI-TOF Mass Spectrometry (Bruker Daltonics, Germany). Criteria for reliable identification were a score of $\geq 2.0$ at species level (Doan et al., 2012).

\section{Statistical analysis}

The statistical processing of the data obtained from each evaluation was done with Statgraphics Plus version 5.1 (AV Trading, Umex, Dresden, Germany). For each replication, the mean was calculated and data were log transformed.

\section{Results and discussion}

In our study, the LAB counts isolated from grape berries ranged from 2.24 in Welchriesling to $3.33 \mathrm{log}$ cfu. $\mathrm{mL}^{-1}$ in Merlot. The LAB counts in must varied from 3.1 in Blue Portugal to $3.24 \log$ cfu. $\mathrm{mL}^{-1}$ in Welschriesling. For wine, the LAB counts were reported from 1.17 in Blue Portugal to 2.09 log cfu. $\mathrm{mL}^{-1}$ in Palava (Table 1).

Winery environment is expected to be the main source of microorganisms associated with winemaking. Despite the significance of $L A B$ in wine production, the limited number of studies describes their isolation from grapes (Fleet, 2001). The $L A B$ counts were from $0.48 \log$ cfu. $\mathrm{mL}^{-1}$ to 2.06 $\log$ cfu.mL $\mathrm{L}^{-1}$ in Cabernet Sauvignon and Blaufränkisch, but negative results were obtained from white grape varieties (Kántor et al., 2015). Previously reported LAB counts for LAB ranged from 3.12 to 3.24 and 1.17 to 2.09 log cfu.mL ${ }^{-1}$ for must and wine, respectively (Kántor et al., 2015). In total, five genera of $L A B$ were identified in the present study (Table 2). Lactobacillus spp. was the most abundant (39\%) while Pediococcus and Weissella the least abundant with 7\% of distribution for each genera (Table 2).

Obligately homofermentative $L$. alimentarius with 36 isolates was the most abundant Lactobacillus (Table 3). The least abundant Lactobacillus spp. were L. coryniformis and $L$. paracasei with 10 isolates for each species. The predominant LAB were Leuconostoc mesenteroides ssp. mesenteroides with 251 isolates and Lactococcus lactis with 121 isolates. $L A B$ species normally form a part of microbiota of grapes, musts and wines. Different LAB

Table 1 Number of lactic acid bacteria in log cfu. $\mathrm{mL}^{-1}($ mean \pm SD)

\begin{tabular}{|c|c|c|c|}
\hline Sample & Grape & Must & Wine \\
\hline Rheinriesling & $2.49 \pm 0.16$ & $3.21 \pm 0.04$ & $1.25 \pm 0.01$ \\
\hline Welschriesling & $2.24 \pm 0.11$ & $3.24 \pm 0.02$ & $1.27 \pm 0.04$ \\
\hline Palava & $2.52 \pm 0.16$ & $3.20 \pm 0.01$ & $2.09 \pm 0.03$ \\
\hline Pinot Blanc & $2.34 \pm 0.10$ & $3.12 \pm 0.02$ & $1.41 \pm 0.20$ \\
\hline Grüner Veltliner & $2.47 \pm 0.05$ & $3.19 \pm 0.07$ & $1.28 \pm 0.15$ \\
\hline Cabernet Sauvignon & $2.78 \pm 0.03$ & $3.16 \pm 0.05$ & $1.29 \pm 0.05$ \\
\hline Blaufränkisch & $2.74 \pm 0.15$ & $3.17 \pm 0.04$ & $1.27 \pm 0.04$ \\
\hline Blue Portugal & $2.72 \pm 0.14$ & $3.10 \pm 0.02$ & $1.17 \pm 0.07$ \\
\hline Merlot & $3.33 \pm 0.09$ & $3.22 \pm 0.06$ & $1.50 \pm 0.04$ \\
\hline Pinot Noir & $2.45 \pm 0.20$ & $3.16 \pm 0.06$ & $1.18 \pm 0.06$ \\
\hline
\end{tabular}

Table 2 Number of isolated species from all samples together

\begin{tabular}{|l||c|c|c|c|}
\hline Genera & No. of isolates & No. of species & \% of isolates & \% of species \\
\hline \hline Lactobacillus & 356 & 21 & 39.38 & 77.78 \\
\hline Lactococcus & 121 & 1 & 13.38 & 3.70 \\
\hline Leuconostoc & 251 & 1 & 27.77 & 3.70 \\
\hline Pediococcus & 119 & 2 & 13.16 & 7.41 \\
\hline Weissella & 57 & 2 & 6.31 & 7.41 \\
\hline Total & 904 & 27 & 100 & 100 \\
\hline
\end{tabular}


species may be present in must and wines, and usually they include heterofermentative cocci of Leuconostoc and Oenococcus, homofermentative cocci of Pediococcus of Lactobacillaceae, homofermentative, facultative, and strict heterofermentative $L A B$ of Lactobacillaceae family (Fugelsang and Edwards, 2007). In wine grapes of Australian vineyards, (Bae et al., 2006) there were detected Lactococcus and Weissella which is in line with our results.

Lactobacillus acidophilus in different wine samples of Slovak origin ranged from 1 to 105 cfu. $\mathrm{mL}^{-1}$

Table 3 Number of LAB isolates from grape, must and wine

\begin{tabular}{|c|c|c|c|c|}
\hline \multirow[t]{2}{*}{ Species of microorganisms } & Grape & Must & Wine & Total \\
\hline & \multicolumn{4}{|c|}{ No. of isolates } \\
\hline Lactobacillus acidophilus & 5 & 15 & 7 & 27 \\
\hline Lactobacillus alimentarius & 10 & 20 & 6 & 36 \\
\hline Lactobacillus amylolyticus & 15 & 0 & 10 & 25 \\
\hline Lactobacillus brevis & 5 & 0 & 10 & 15 \\
\hline Lactobacillus casei & 0 & 8 & 4 & 12 \\
\hline Lactobacillus coryniformis & 3 & 5 & 2 & 10 \\
\hline Lactobacillus delbrueckii ssp. delbrueckii & 5 & 8 & 5 & 18 \\
\hline Lactobacillus fermentum & 18 & 0 & 0 & 18 \\
\hline Lactobacillus fructivorans & 5 & 5 & 2 & 12 \\
\hline Lactobacillus hilgardii & 5 & 5 & 2 & 12 \\
\hline Lactobacillus nageli & 15 & 0 & 0 & 15 \\
\hline Lactobacillus oligofermentans & 10 & 8 & 0 & 18 \\
\hline Lactobacillus oris & 5 & 8 & 2 & 15 \\
\hline Lactobacillus parabuchneri & 10 & 12 & 3 & 25 \\
\hline Lactobacillus paracasei & 10 & 0 & 0 & 10 \\
\hline Lactobacillus paracasei ssp. paracasei & 10 & 6 & 0 & 16 \\
\hline Lactobacillus paracasei ssp. tolerans & 10 & 5 & 0 & 15 \\
\hline Lactobacillus pentosus & 15 & 0 & 0 & 15 \\
\hline Lactobacillus plantarum & 5 & 6 & 5 & 16 \\
\hline Lactobacillus saerimneri & 14 & 0 & 0 & 14 \\
\hline Lactobacillus sakei & 12 & 0 & 0 & 12 \\
\hline Lactococcus lactis & 35 & 65 & 21 & 121 \\
\hline Leuconostoc mesenteroides ssp. mesenteroides & 80 & 126 & 45 & 251 \\
\hline Pediococcus acidilactici & 20 & 25 & 7 & 52 \\
\hline Pediococcus pentosaceus & 20 & 35 & 12 & 67 \\
\hline Weissella spp. & 15 & 10 & 7 & 32 \\
\hline Weissella uvarum & 25 & 0 & 0 & 25 \\
\hline Total & 382 & 372 & 150 & 904 \\
\hline
\end{tabular}

from wine samples with score higher than 2 were identified (Table 3).

Altogether, 21 species of Lactobacillus were found in our study. The positive and negative properties of Lactobacillus sp. in wine have been intensively investigated in the recent years (Manes-Lazaro et al., 2009). Studies of wine-associated Lactobacillus species are necessary to recognize those responsible for wine spoilage. This fundamental information could be addressed through the identification and enumeration of the $L A B$ at different stages of vinification (Dols-Lafargue, 2018).

In conclusion, the wine-making microbiota is associated with the microorganisms of grapes, must and vinery environment; hence, the changes in the equilibrium of microbiota could alter the acceptance of wine with both the main quality and safety characteristics which may be affected (Capozzi et al., 2017). The microbiological composition of grape impacts the wine quality highlighting the effects of raw material in winemaking (Berbegal et al., 2019).

\section{Conclusions}

In our study, ten different varieties ( $n=90$ ) of grapes, musts and wines samples were evaluated. The numbers of isolated $L A B$ ranged between the grape, must and wine samples with 904 isolates which were selected for further identification with MALDI-TOF Biotyper. In terms of LAB diversity, three family of $L A B$ were isolated including Lactobacilaceae, Leuconostocaceae and Streptococcacea represented by five different genera and 27 species. The most abundant species in our study were Lactococcus lactis and Leuconostoc mesenteroides spp. mesenteroides in all types of matrixes. MALDI-TOF MS Biotyper was the appropriate method for quick identification of LAB from grape, must and wine.

\section{Acknowledgments}

The paper was supported by the project: The research leading to these results has received funding from the European Community under the project no. 26220220180: Building Research Centre "AgroBioTech". 


\section{References}

BERBEGAL, C. - FRAGASSO, M. - RUSSO, P. - BIMBO, F. - GRIECO, F. - SPANO, G. - CAPOZZI, V. Climate Changes and Food Quality: The Potential of Microbial Activities as Mitigating Strategies in the Wine Sector. In Fermentation, vol. 5, 2019, pp. 85.

CAPOZZI, V. - FRAGASSO, M. - ROMANIELLO, R. - BERBEGAL, C. - RUSSO, P. - SPANO, G. Spontaneous Food Fermentations and Potential Risks for Human Health. In Fermentation, vol. 3, 2017, pp. 49.

DOLS-LAFARGUE, M. Polysaccharide Production by Wine Lactic Acid Bacteria: Negative Trait or Potential Advantage? A Review. In Applied Microbiology, vol. 4, 2018, pp. 143.

FLEET, G.H. Wine. In Food Microbiology Fundamentals \& Frontiers ed. DOYLE, M.P. - BEUCHAT, L.R. - MONTVILLE, T.J. Washington DC : ASM Press, 2001, pp. 747-772.

FUGELSANG, K.C. - EDWARDS, C.G. Wine Microbiology: Practical Applications and Procedures. $2^{\text {nd }}$ ed. New York, USA : Springer, 2007, $393 \mathrm{p}$.

GARRITY, G.M. - BELL, J.A. - LILBURN, T.G. Taxonomic outline of the Procaryotes. Bergey's Manual of Systematic Bacteriology. $2^{\text {nd }}$ ed. New York : Springer-Verlag, 2004.

KAČÁNIOVÁ, M. - HLEBA, L. - POCHOP, J. - KADASI-HORAKOVA, M. FIKSELOVA, M. - ROVNÁ, K. Determination of wine microbiota using classical method, polymerase chain method and Step One RealTime PCR during fermentation process. In Journal of Environmental Science and Health, Part B, vol. 47, 2012, pp. 571-578.

KÁNTOR, A. - KAČÁNIOVÁ, M. - KLUZ, M. Natural microflora of wine grape berries. In Journal of Microbiology, Biotechnology and Food Science, vol. 4, 2015, no. 1, pp. 32-36.

MAKAROVA, K. - SLESAREV, A. - WOLF, Y. - SOROKINE, A. - MIRKIN B. - KOONIN, E. - PAVLOV, A. - PAVLOVA, N. - KARAMYCHEV, V. - POLOUCHINE, N. - SHAKHOVA, V. - GRIGORIEV, I. - LOU, Y. - ROHKSAR, D. - LUCAS, S. - HUANG, K. - GOODSTEIN, D.M. HAWKINS, T. - PLENGVIDHY, V. - WELKER, D. - HUGHES, J. - GOH, Y. - BENSON, A. - BALDWIN, K. - LEE, J.H. - DIAZ-MUNIZ, I. DOSTI, B. - SMEIANOV, V. - WECHTER, W. - BARABOTE, R. - LORCA, G. - ALTERMANN, E. - BARRANGOU, R. - GANESAN, B. - XIEF, Y. - RAWSTHORNE, H. - TAMIR, D. - PARKER, C. - BREIDT, F. BROADBENT, J. - HUTKINS, R. - O'SULLIVAN, D. - STEELE, J. - UNLU, G. - SAIER, M. - KLAENHAMMER, T. - RICHARDSON, P. - KOZYAVKIN, S. - WEIMER, B. - MILLS D. Comparative genomics of lactic acid bacteria. Proceedings of the National Academy of Sciences of the United States of America, vol. 42, 2006, pp. 15611-15616.
MANES-LAZARO, R. - FERRER, S. - ROSSELLO-MORA2AND, R. PARDO, I. Lactobacillus oeni sp. nov., from wine. In International Journal of Systematic Evolutionary Microbiology, vol. 59, 2009, pp. 2010-2014.

MIRANDA-CASTILLEJA, D.E. - MARTINEZ-PENICHE, R.A. - ALDRETETAPIA, J.A. - SOTO-MUNOZ, L. - ITURRIAGA, M.H. - PACHECOAGUILAR, J.R. - ARVIZU-MEDRANO, S.M. Distribution of native lactic Acid Bacteria in Wineries of Queretaro, Mexico and Their Resistance to Wine-Like Conditions. In Frontiers in Microbiology, vol. 7, 2016, pp. 1769

MTSHALI, P.S. - DIVOL, B. - VAN RENSBURG, P. - DU TOIT, M. Genetic screening of wine-related enzymes in Lactobacillus species isolated from South African wines. In Journal of Applied Microbiology, vol. 108, 2009, no. 4, pp. 1389-1397.

POZO-BAYON, M.A. - G-ALEGRIA, E. - POLO, M.C. - TENORIO, C. - MARTÍN-ÁLVAREZ, P.J. - CALVO DE LA BANDA, M.T. - RUIZLARREA, F. - MORENO ARRIBAS, M.V. Wine volatile and amino acid composition after malolactic fermentation: Effect of Oenococcus oeni and Lactobacillus plantarum starter cultures. In Journal of Agriculture and Food Chemistry, vol. 53, 2005, pp. 8729-8735.

RODRÍGUEZ-SÁNCHEZ, B. - ALCALÁ, L. - MARÍN, M. - RUÍZ, A. ALONSO, E. - BOUZA, E. Evaluation of MALDI-TOF MS (MatrixAssisted Laser Desorption-lonization Time-of-Flight Mass Spectrometry) for routine identification of anaerobic bacteria. In Anaerobe, vol. 42, 2016, pp. 101-107.

RUIZ, P. - IZQUIERDO, P.M. - SESE'NA, S. - PALOP, M.L. Analysis of lactic acid bacteria populations during spontaneous malolactic fermentation of Tempranillo wines at five wineries during two consecutive vintages. In Food Control, vol. 21, 2010, no. 1, pp. 70-75.

SPANO, G. - MASSA, S. Environmental stress response in lactic acid bacteria: beyond Bacillus subtillis. In Critical Review in Microbiology, vol. 32, 2006, pp. 77-86. 